\title{
BMJ Global Health Addressing upstream determinants of health in Germany's new global health strategy: recommendations from the German Platform for Global Health
}

\author{
Jens Holst ${ }^{\oplus}$
}

\begin{abstract}
To cite: Holst J. Addressing upstream determinants of health in Germany's new global health strategy: recommendations from the German Platform for Global Health. BMJ Glob Health 2019;4:e001404. doi:10.1136/ bmjgh-2019-001404
\end{abstract}

Handling editor Seye Abimbola

Received 8 January 2019 Revised 6 March 2019 Accepted 9 March 2019

\section{Sinked}

- http://dx.doi.org/10.1136/ bmjgh-2018-001140

Check for updates

(C) Author(s) (or their employer(s)) 2019. Re-use permitted under CC BY-NC. No commercial re-use. See rights and permissions. Published by BMJ.

\section{Correspondence to}

Professor Jens Holst,Nursing and health sciences, Hochschule Fulda, Fulda, Germany; jens.holst@pg.hs-fulda.de

\section{INTRODUCTION}

Just 5 years after adopting the first global health concept, the German government is currently preparing a new strategy paper for implementing a coherent global health policy. ${ }^{1}$ Public-health experts had warned at the time that the 2013 strategy might fail to make a consolidated contribution to solving global health challenges. The former concept exhibited important gaps, particularly in the areas of non-medical determinants of health, national and global inequity, and universal social protection for migrants, refugees and sans papiers. ${ }^{2}$

This journal published recently a paper containing procedural recommendations for the further elaboration of the strategy. ${ }^{3}$ Accordingly, the German Platform for Global Health (DPGG), an association of trade unions, non-governmental organisations and researchers, wants to highlight a series of crucial content issues which are indispensable for effectively contributing to global health. Germany's growing role as global health actor ${ }^{4}$ calls for a multidisciplinary, coherent policy for improving people's health worldwide.

For the relaunch of the global health strategy paper, the Federal Government organised two preparatory meetings with civil society and invited different actors to elaborate their priority recommendations. ${ }^{5}$ In the context of the participatory process initiated by the government, the DPGG, an association of trade unions, non-governmental organisations and researchers, sees the need to highlight a series of recommendations which will be crucial for making an effective and convincing contribution to the global health agenda. In particular, Germany's growing role as global health actor calls for a balanced, multidisciplinary, coherent and problem-oriented policy for contributing to significant and sustained improvement in people's health worldwide.

\section{Summary box}

To strengthen its expanding role in global health, the German government is currently preparing a new global health strategy, to be published in 2019.

- As social, political and economic determinants are highly relevant for population health, the German government will need to increase coherence in order to promote its emphasis on creating equal opportunities and reducing inequalities in and between countries.

- For further strengthening its commitment to universal health coverage, for promoting decent work and healthy labour conditions, and for enforcing the right to health, the German government will have to stress the mandatory role of the public sector for global health.

Based on a broad array of expertise, the platform aims to emphasise the importance of the social determinants of health in both the national and international health debate. ${ }^{6}$ In today's globalised world, the key conditions of people's well-being and health are no longer steerable at the national level alone. Any comprehensive approach has to acknowledge that global health starts at home. The DPGG strives to bridge the divide between national and global health policies. Therefore, it has developed some essential recommendations for the new global health strategy.

\section{EQUAL HEALTH OPPORTUNITIES WORLDWIDE}

Health is both a public good and a human right. All over the world, health opportunities depend strongly on social conditions and status and not so much on individual health behaviours. People with lower education and income fall ill and die earlier than members of the upper socioeconomic class. ${ }^{7}$ These health inequalities cannot be explained by lower availability or use of health services 
alone $^{8}$ because even comprehensive social protection and healthcare systems such as those in France, Germany or the UK do not alter the fact that life expectancy for the poorest quintile is shorter by many years, on average, than for the richest $20 \%$ of the population. ${ }^{9}$ Developing and exporting innovative technological and pharmaceutical products as proposed by the first German global health strategy is not very likely to reduce inequalities. ${ }^{1011}$ Given the disparities in the health and life chances are not ordained by nature but caused by social conditions and can therefore be influenced by political measures.

Responsible global health policies should strive to reduce these inequalities. Restricting health and illness to personal responsibility is the wrong way to go and heightens inequalities rather than reducing them. ${ }^{12} 13$ Health policy tends to rather address the causes of disease as individual risk factors and to pay little attention to paramount factors such as the social, environmental, structural and political determinants of health and disease. ${ }^{14} 15$

The forthcoming global health strategy of the German Government should therefore highlight the promotion of healthy living and environmental conditions at local, national and global levels. Health policy has to be cross-sectoral and target all areas that directly or indirectly affect people's well-being and health. Despite all declarations of intent, both the commitment to social determinants of health and policy coherence are still to be seen. To become a powerful contribution for improving global health, the new German global health strategy ultimately will have to provide means for assessing all policy areas for their health impacts both in national and global policies.

\section{SOCIAL PROTECTION FOR ALL}

In many countries in the global south, but also in the north, neoliberal policies such as structural adjustment, austerity programmes and privatisation have put pressure on or even dismantled public social security systems. ${ }^{16}$ Protecting citizens from social risks, however, is not a mere economic cost factor but a state obligation and the foundation of individual and economic development and social welfare. ${ }^{17}$ In the case of illness, unemployment and disability, people must be able to rely on effective social protection systems.

The Sustainable Development Goals also require Germany to offer social protection to everybody living in the country. ${ }^{18}$ In particular, Sustainable Development Goal 3.8 aims at universal health coverage making health benefits fully available to asylum seekers, non-working European Union citizens and all people without a regular residence permit. At the global level, special emphasis has to be placed on strengthening social protection systems, especially in poor countries of the south. Therefore, a global health strategy should always include universal health coverage and social protection-both in that country and elsewhere in the world.

Strengthening health and social systems through international cooperation will not suffice in itself. The sustainable improvement of social and living conditions of all people on earth requires fair use of national resources, economic participation and financial support of poor societies and their people. The global health strategy should therefore underpin the universal right to social protection and mitigation of social risks; promote sustainable and solidarity-based financing of social security systems worldwide; and establish global financial equalisation mechanism for social benefits, and particularly for social protection in the case of illness.

\section{DECENT AND HEALTH-PROMOTING LABOUR}

Adequate protection of the life and health of the working population, as well as social protection to safeguard minimum income and comprehensive medical care, have long been central objectives of the international community. However, global market competition is putting pressure on labour standards worldwide. ${ }^{19}{ }^{20}$ Except for few emerging countries, macroeconomic growth has not led to a tangible reduction of informal and unstable employment. ${ }^{21}{ }^{22}$ Safety, well-being and health of the working population are often subordinated to the pursuit of growth and profit. Even worse is the situation for the unemployed, who face high risks of illness and death, ${ }^{23}$ for about 20 million people obliged to work as forced labourers, and over 200 million working children worldwide. ${ }^{24}$ Therefore, a global health strategy should include actions to reduce detrimental risk factors for health, such as job insecurity, precarious employment, poor working conditions and lack of social protection for the informal sector and unemployed.

In today's global economic order, low wages, savings on health and safety protection in the workplace, flexible and unstable employment conditions, and weak trade unions or none at all, are considered positive business factors. Until the logic of short-term profit maximisation and growth at any price can be reversed, equity in health remains unattainable. The global health strategy of the Federal Government has to consider both the working conditions of people all over the globe, and the responsibility of German and international companies. Global health requires responsible, participatory governance of the global economy which respects economic, social, environmental and health aspects and reconciles different interests.

\section{CONCLUSION}

Despite the respective provision of the 1948 Universal Declaration of Human Rights and the 1966 Social Pact of the United Nations, the implementation of the right to health remains a global challenge. The WHO explicitly makes governments responsible for the state of health of the population. ${ }^{25}$ Although civil society involvement is important, states should not shift that responsibility to them.

Privatisations and public-private partnerships, supposed solutions for tight budgets, are showing undesirable effects 
such as rising consumer prices, lack of control over public funds and growing inequalities. ${ }^{26}$ At the global level, the sheer financial power of private philanthropy influences priority-setting and independence of public policy and poses challenges to global health governance. Private companies are but one among several civil-society actors, and their interests are often in contrasts with other groups of society. Without preserving and strengthening public social responsibility, the right to health remains unattainable. It is first and foremost the duty of states to ensure the social and institutional framework, bear responsibility for unimpeded access to care for all and reduce health inequalities. While the German global health strategy should involve civil society, it also has to emphasise the mandatory role of the public sector in providing social services, security and healthcare.

Contributors $\mathrm{JH}$ is the only author and contributor to this commentary edited for the German Platform for Global Health. He had the original idea for and prepared the first draft of this commentary.

\section{Competing interests None declared.}

Patient consent for publication Not required.

Provenance and peer review Not commissioned; externally peer reviewed.

Data sharing statement No additional data are available.

Open access This is an open access article distributed in accordance with the Creative Commons Attribution Non Commercial (CC BY-NC 4.0) license, which permits others to distribute, remix, adapt, build upon this work non-commercially, and license their derivative works on different terms, provided the original work is properly cited, appropriate credit is given, any changes made indicated, and the use is non-commercial. See: http://creativecommons.org/licenses/by-nc/4.0/.

\section{REFERENCES}

1. The Federal Government. Shaping global health. taking joint action. embracing responsibility: the federal government's strategy paper, 2013. Available: https://www.bundesgesundheitsministerium.de/ fileadmin/Dateien/5_Publikationen/Gesundheit/Broschueren/Screen Globale_Gesundheitspolitik_engl.pdf [Accessed 2 Jan 2019].

2. Bozorgmehr K, Bruchhausen W, Hein W, et al. Germany and global health: an unfinished agenda? The Lancet 2013;382:1702-3.

3. Stratil JM, von Philipsborn P, Marckmann G, et al. Advancing Germany's new global health strategy. BMJ Glob Health 2018;3:e001140.

4. Kickbusch I, Franz C, Holzscheiter A, et al. Germany's expanding role in global health. The Lancet 2017;390:898-912.

5. Meldungen. Neue Schwerpunkte für die globale Gesundheitspolitik. Available: https://www.bundesgesundheitsministerium.de/ ministerium/meldungen/2018/september/globale-gesundheitspolitik. html
6. DPGG. Deutsche Plattform für Globale Gesundheit - Basispapier. Berlin: Deutsche Plattform für Globale Gesundheit, 2013. Available: http://plattformglobalegesundheit.de/wp-content/uploads/2015/07/ plattform-fuer-globale-gesundheit.pdf [Accessed 29 Dec 2018].

7. Marmot M, justice S. Epidemiology and health inequalities. Eur J Epidemiol 2017;32:537-46.

8. Tyrovolas S, Polychronopoulos E, Tountas Y, et al. The role of health care systems on populations' health status and longevity: a comprehensive analysis. Health Science Journal 2010;4:149-56.

9. Mackenbach JP, Kulhánová I, Artnik B, et al. Changes in mortality inequalities over two decades: register based study of European countries. BMJ 2016;353.

10. Phelan J, Link B. Evidence, and policy implications. J Health Soc Behav 2010;51:S28-40.

11. Weiss D, Eikemo TA. Technological innovations and the rise of social inequalities in health. Scand J Publ Health 2017;45:714-9.

12. Friesen P. Personal responsibility within health policy: unethical and ineffective. J Med Ethics 2018;44:53-8.

13. Schrecker T, 'Run B, Knit. And relax': can health promotion in Canada advance the social determinants of health agenda? Healthc Policy 2013;9:48-58.

14. Wikler D. Personal and social responsibility for health. Ethics int. aff. 2002;16:47-55.

15. Schmidt B. Die Sanierung Der Eigenverantwortung. Jahrbuch für kritische Medizin und Gesundheitswissenschaften 2013;46:51-68.

16. Labonté R, Stuckler D. The rise of neoliberalism: how bad economics imperils health and what to do about it. J Epidemiol Community Health 2016;70:312-8.

17. Jamison DT, Summers LH, Alleyne G, et al. Global health 2035: a world converging within a generation. The Lancet 2013;382:1898-955.

18. United Nations. Sustainable development Goals. New York: United Nations, 2015. Available: https://www.un.org/sustainabledevel opment/sustainable-development-goals [Accessed 1 Jan 2019].

19. Peters J. Labour market deregulation and the decline of labour power in North America and Western Europe. Policy and Society 2008;27:83-98.

20. Reddy N. Challenges of decent work in the globalising world. Indian Journal of Labour Economics 2005;48:3-17.

21. Ocampo JA, Vallejo J. Economic growth, equity and Human development in Latin America. J Human Dev Capabil 2012;13:107-33.

22. Verick S. The impact of globalization on the informal sector in Africa. Addis Abeba / Munich: economic and social policy division, United Nations economic Commission for Africa (ECA) / Institute for the study of labor (IZA), 2011. Available: https:// pdfs.semanticscholar.org/32bd/5feb7888fc057dc0967a1a623ec7 4d9e53c0.pdf

23. Clemens T, Popham F, Boyle P. What is the effect of unemployment on all-cause mortality? A cohort study using propensity score matching. Eur J Public Health 2015;25:115-21.

24. International Labour Office. Global estimates of modern slavery. Forced labour and forced marriage. Geneva: International Labour Office, 2017.

25. Gostin LO, Heywood M, Ooms G, et al. National and global responsibilities for health. Bull World Health Organ 2010;88:719-719A.

26. Languille S. Public private partnerships in education and health in the global South: a literature review. J Int Compar Soc Pol 2017;33:142-65. 